\title{
Pseudo-John Chrysostom's Homily On Susanna (CPG 4567) (Daniel 13 LXX): Masculinity, psychic typology and the construction of early Christian salvation history
}

\begin{abstract}
Author:
Chris L. de Wet ${ }^{1,2}$ (1)

Affiliations:

${ }^{1}$ Department of Biblical and Ancient Studies, College of Human Sciences, University of South Africa, Pretoria, South Africa
\end{abstract}

${ }^{2}$ Australian Lutheran College, University of Divinity, Adelaide, Australia

Corresponding author: Chris L. de Wet, chrisldw@gmail.com

Dates:

Received: 02 Sept. 2021

Accepted: 17 Sept. 2021

Published: 15 Dec. 2021

How to cite this article: De Wet, C.L., 2021, 'Pseudo-John Chrysostom's Homily On Susanna (CPG 4567) (Daniel 13 LXX): Masculinity, psychic typology and the construction of early Christian salvation history', HTS Teologiese Studies/ Theological Studies 77(4), a7116. https://doi. org/10.4102/hts.v77i4.7116

\section{Copyright:}

C 2021. The Authors. Licensee: AOSIS. This work is licensed under the Creative Commons Attribution License.
This article investigates a short Greek Christian homily, from the 4th century CE, by an anonymous Cappadocian preacher on the narrative of Susanna in Dan 13 LXX. The homily is simply titled, On Susanna (CPG 4567), and has been erroneously transmitted as a work of John Chrysostom. The purpose of this article is to examine more closely the construction of Susanna in the homily, with specific reference to the use of masculinity, psychic typology and finally, the construction of early Christian salvation history. After addressing, in brief, some matters of canonicity, a close reading of On Susanna is given. It is demonstrated that the Cappadocian strategically constructs Susanna like a virginal Christian martyr and ascetic, with the aim of highlighting her masculine steadfastness and dominance in her contest (agōn) against the elders. A significant second move that is made in the homily is to position the masculine Susanna as a type for the soul of the individual, which should also be guarded against the onslaught of sin and the passions.

Contribution: This Christian reconstruction of Susanna brings the subjectivity of the individual listener in the audience, and the character of Susanna, in close proximity to one another. In effect, by internalising the narrative of Susanna into the realm of the soul, the anonymous Cappadocian preacher is able to utilise a layered biblical salvation history that incorporates not only narratives from the Bible, but also the audience member's own individual narrative and struggles into the grander scheme of salvation history.

Keywords: Susanna; Daniel 13 LXX; pseudo-John Chrysostom; early Christianity; Patristics.

\section{Introduction}

The Rezeptionsgeschichte of the Old Testament (OT) apocryphal (or deuterocanonical) writings in early Christianity is as complex as it is interesting. When one surveys the various sources, including canon lists and writings discussing canonical matters, it soon becomes evident that many in the Latin church of the West were keen to accept some apocryphal works as canonical. The Greek church of the East displays more reservation with accepting apocryphal materials into canon lists. The one point of continuity that should be pointed out is that the majority of early Christian authors, whether from the West or the East, did ascribe some value and authority to the OT apocrypha. Some considered these apocryphal writings to be canonical, while others considered them useful for the so-called 'ecclesiastical' purposes. Of these 'ecclesiastical' purposes, we find that many apocryphal works and narratives were used in the teaching of catechumens and church members more generally. What this means is that OT apocryphal stories, as didactic tools, often functioned as disciplinary apparatuses towards Christian moral formation. Characters from these stories served as moral exempla, teaching Christians how to live a virtuous life and how to avoid vice.

Among the OT apocryphal narratives, few were as influential as the story of Susanna, an addition to the Book of Daniel (ch. 13 in the LXX). The canonicity of apocryphal additions is in itself somewhat complicated. While individual books, like Tobit or Judith, could easily be relegated as canonical or ecclesiastical, it is not always clear whether additions to books that were considered canonical assumed the same status. Origen, for instance, saw Susanna as an original part of the text of Daniel, despite the fact that he knew the Jews did not consider Susanna as authoritative (Letter to Julius Africanus 9). Cyril of Jerusalem, in his Catechesis 4.35, seems to consider the additions to Daniel, which included Susanna and Bel and the Dragon, as canonical along with the whole Book of Daniel (see Gallagher \& Meade 2017:115n194), while it is not that clear 
in the case of Athanasius (Festal Letter 39.17; Gallagher \& Meade 2017:126). Whether Susanna was considered canonical or not, there is no disputing the popularity of the narrative in early Christian preaching and teaching (on the reception of Susanna in early Christianity, see De Wet 2009:229-44; Praet 2011:556-80).

The purpose of this study is to closely examine a homily On Susanna (PG 56.589-94; CPG 4567), pseudonymously attributed to the popular 4th-century Christian bishop and preacher, John Chrysostom (ca. 349-407 CE). Despite its interesting offering, the homily is quite neglected in scholarship. While On Susanna was transmitted under Chrysostom's name, Voicu (2013:1197-1221) has grouped this homily (out of 37 others) as originating from an anonymous Cappadocian preacher who was in Constantinople at more or less the same time as Chrysostom (see also Papadopoulos [2017], who provides very useful details on the manuscript history and an accompanying translation ${ }^{1}$ ). This homily is commonly transmitted with another homily, probably by the same preacher, On Joseph and on Chastity (CPG 4566). On Susanna, as well as the homily On Joseph, have chastity as their main theme. This study will give special attention to how the Cappadocian preacher reconstructs Susanna as an example of Christian virtue and chastity, and to what ends. This study aims to contribute not only to our understanding of the reception of Susanna in the early church, but to understand more critically the literary-ascetic power strategies used by Christian preachers in late antiquity to shape morality and, in particular, masculinity and sexual ethics. In conclusion, I also argue that the typological interpretation of Susanna, as is evident in this homily, is evidence of an early Christian move to internalise biblical salvation history, and to make it eclipse with the subjectivity of the Christian believer. ${ }^{2}$ Up to this point, and to my knowledge, there is no focussed and sustained analysis of the contents of this homily, except for Papadopoulos's translation and manuscript notes.

\section{Between poverty and chastity: Reading Susanna through the lens of masculinity}

Clark (1999:3), in her magisterial work, Reading Renunciation: Asceticism and Scripture in Early Christianity, shows that early Christian ascetic writers grounded 'their renunciatory program in the Bible'. Clark especially demonstrates how closely related ascetic discourse was to gender discourse. The Susanna narrative is no exception in this case. The very nature of the story and its main female protagonist lent itself quite easily to such asceticizing strategies. On Susanna displays a rich tapestry of asceticizing strategies in its interpretation of Dan. 13 LXX. In fact, even the brevity of the homily is justified in a rather ascetic tone. The author states:

1.I will use Papadopoulos's (2017) translation and numbering of On Susanna in this article. The Greek text is found in volume 5 of Mignes (ed. 1862), henceforth PG.

2.I especially thank Katherin Papadopoulos (Australian Lutheran College, University of Divinity, Adelaide) for her insight into guidance with the homily, especially its text, transmission and translation.
We come to you right-minded, owing you an address, not rendering as much as we are obligated to pay, but as much as we are able to give. For our willingness is abundant and spread out to give even more than what is owed, but the poverty of our speech constrains. And should anyone of you wish to measure the paucity of our words against the willingness of our heart, we will not fall short of what is owed, since our willingness supplies the deficient part of the word. For even God, whenever he sees the trifling offerings of a poor man and the abundant ones of a rich man, knows to receive honours equally, but often he accepts those of the poor man more readily. For he does not look at the amount of money but at the willingness of the heart. And a proof of what <we are $>$ saying $<$ is $>$ the case of the needy widow, who put the two coins in the treasury, for before God, her trifling offering outweighed the gold put in by the rich, since God has no need of money, but of pure and rightly intentioned hearts. (On Susanna 2-12 [PG 56.589])

What is interesting about this opening of the homily is that the author justifies the form of the homily - its brevity and, possibly, simplicity (at least, its straightforwardness) - in ascetic terms. This was an important strategy in early Christian discourse. In Roman antiquity, eloquence was a defining characteristic of masculinity, although this changed in early Christian discourse. The quality of one's speech was no longer an exclusive marker of manliness (although eloquence was still admired). Rather, it was simplicity, poverty and sincerity of speech that defined early Christian masculinity. This is because, as Kuefler (2001) has shown, the monk became the new model of early Christian masculinity. Ascetic values such as poverty, humility and simplicity were transferred to one's speech. Poverty $(\pi \varepsilon v i ́ \alpha)$ was a notable ascetic trait (see e.g. Brown 2002). We therefore see that the author, at the outset, fashions his own identity and masculinity in ascetic terms. He compares the poverty of his speech to the actions of the widow in Mark 12:41-44. The use of this character might not be incidental. The office of the widow was a respected one in the early church (Walsh 2008:176-86), and the figure of the widow and her offering functions as a suitable precursor to the discourse of the main woman of the homily, Susanna. He prepares his audience for a martyrological-ascetic discourse that will, essentially, highlight manly women as exemplars of Christian morality (see Cloke [1995] for more on the masculinisation of women in early Christian ascetic discourse). The use of female exemplars to demonstrate masculine ideals of virtue was popular, as it democratised virtue formation to a large extent. Such a discourse could shame men who were unable to demonstrate virtue and also implied that women and even slaves were not exempt from the standards of Christian masculine virtue.

The author then proceeds to construct Susanna as an ideal

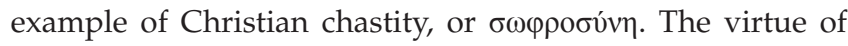

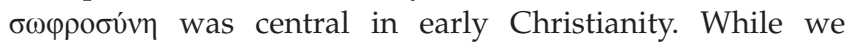
might conventionally, and rightly, understand the term as chastity (as opposed to the more classical understanding of 'moderation'), the concept also relates to the notion of moral discipline and restraint (De Wet 2015:206-207). He writes 
(On Susanna 14): 'For I remember promising you yesterday that $<$ I would $>$ preach $<$ on $>$ the struggle of blessed Susanna's

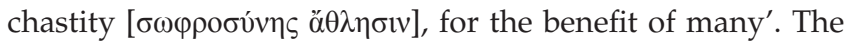
use of the term 'struggle of chastity', or $\sigma \omega \varphi \rho о \sigma v ́ v \eta \varsigma ~ \alpha ̈ \theta \lambda \eta \sigma ı$, is significant and will receive attention in the following discussion.

Like $\pi \varepsilon v i ́ \alpha, \sigma \omega \varphi \rho \circ \sigma u ́ v \eta$ was a defining ascetic characteristic, and therefore also a marker of masculinity. But in the case of Susanna, in this homily, the matter of chastity is complicated. The problem for many authors would have been the fact that Susanna is a married woman. In early Christianity, the greatest accolade of chastity, especially for women, would have been to remain an unmarried virgin. Marriage came a far second to this (see Elm 1996:25-59; Hunter 2007:87-129). But with the interpretation of the Susanna narrative by the Cappadocian preacher, we see the lines between the virginal and married status being blurred, and while Susanna is married, she is reconstructed in strikingly virginal terms. This is convenient for the author, as Susanna functions, then, equally well as a model for imitation both for virgins and married persons. In On Susanna 24, where she is compared to the soul, Susanna is seen as 'a virgin in some bridechamber', and in section 39, the virginal language is equally apparent. Yet, her marital fidelity is also frequently stressed. 'For the blessed woman happened to be just like a garden, which no one could plunder, exuding the aromas of chastity', says the Cappadocian, 'and she was just like a well sealed by faith, out of which none of the unruly could draw the beauty of her chastity' (On Susanna 39). So, even though she is married, she is described as what we might call a spiritual or psychic virgin.

The link between chastity and masculinity in early Christian thought is well summarised by Kuefler (2001:174):

[C]hastity [castitas in Latin] subsumed all of the sexual virtues of pudicitia [modesty] in late antiquity - virginity before marriage, sexual moderation and fidelity during marriage, and sexual continence in widowhood after marriage - and gave them a Christian coloring. (see also Wilkinson 2015:5-27)

But Kuefler (2001) continues to make an important further observation in this regard:

[C]hastity was resistance to $\sin$, a refusal to succumb to the weakness of temptation that had banished Adam and Eve from Paradise. The association of sexual renunciation with steadfastness and strength, in turn, helped to give it a masculine flavor and appeal. (p. 174)

Chastity was therefore not masculine in and of itself; chastity was not constructed as fleeing from sexual temptation. Rather, chastity was reconceived as a battle against the passions, sin and indeed, the devil himself. Hence the expression,

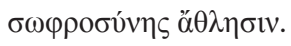

This rhetoric is then present in De Susanna in the author's use of agonistic language, or the language of the contest ( $\dot{\alpha} \gamma \tilde{\omega} \nu$ and $\alpha \dot{\alpha} \theta \lambda \eta \sigma 1 \varsigma)$. The author constructs a new spectacle, a new theatre, in which Susanna contends, writing:
Therefore, let Susanna, too, contend [ả $\gamma \omega v i \zeta \dot{\varepsilon} \sigma \theta \omega]$ in this public theatre, where God and angels and men and women look on. Let her contend and teach how younger women ought to contend unto death for chastity. (On Susanna 16-17)

Susanna is seen as the great, manly athlete, and her spectacle has a pedagogical impetus. He also states: 'It was the greatest spectacle, and agreeable, a woman [Susanna] boxed with two men [the elders]' (On Susanna 50). He actually uses this point to downplay, somewhat, Joseph's chastity. Joseph's battle was against one woman, Potiphar's wife, while Susanna, being a woman, was outnumbered and fought against two men, and gained victory (On Susanna 47-49). The repetition of the verb $\alpha \gamma \omega v i \zeta \dot{\varepsilon} \sigma \theta \omega$, 'let [her] contend', foregrounds the idea that chaste living is a spiritual battle, indeed, a form of sport and even warfare and soldiery. The discourse takes on a distinctive martyrological flair in the use of this language. Shaw (1996:269-312) has convincingly shown how the agonistic language of the early Christian martyr narratives served to validate the masculinity of the martyrs, including women (see also Cobb 2008). The reconstruction of Susanna as a martyr furthermore affirms the link and continuity between Christian teachings of suffering and martyrdom and ascetic practices. By reconceiving Susanna as a martyr, the Cappadocian sets her up as an exemplum par excellence of asceticism. The practice of claiming heroes of the biblical past, and transforming them into Christian martyrs (before Christ), is not unique to this homily. In one of his authentic works, John Chrysostom does exactly the same with the mother of the Maccabean martyrs from 4 Maccabees. Chrysostom described the mother of the Maccabean martyrs in strikingly similar terms to how the Cappadocian describes Susanna:

$[W]$ hereas in the games in the outside world they scrutinize both age and gender and status, and entry to them is closed off to slaves and women and old men and adolescents, here the theatre is opened up with complete safety to every status, every age group and each gender, so that you might learn in full the generosity and ineffable power of the one who set up the contest, and see that apostolic remark certified in practice: 'his power is perfected in weakness' [2 Cor 12.9]. (John Chrysostom, On the Maccabean Martyrs 1.4; translated by Mayer 2006:139; see also De Wet 2012:3-21, 2018:43-67)

We find a most interesting blurring of theological and social lines in the homily. Susanna's chastity is regarded in highly virginal terms, despite the fact that she was married -implicitly, she appears like both an ideal virgo and noble young matrona. Although she appears quite passive in the narrative, she is actually a highly active player and contender in battle against the passions. She is constructed as both a Christian martyr and ascetic even before Christ. In this way, the Cappadocian thoroughly claims Susanna as Christian corporeal capital, and subsequently, masculinises her to that end.

\section{Masculinity and psychic typology in On Susanna}

It is not enough for the Cappadocian to simply represent Susanna as an exemplum of Christian masculine virtue and 
ascetic discipline for the audience to admire. The illustration needs to be practical, and of relevance to the daily life and behaviour of his audience. Using the homilies of John Chrysostom, Maxwell (2009) has shown that one of the main goals of Christian homiletic communication was to reshape the behavioural habits and identities of the audience. The Cappadocian achieves this goal in a most creative way, by turning the character of Susanna into a typology for the soul. He writes:

For most of <our $>$ sins are a consequence of the senses of our soul. For the soul, just as a virgin in some bridechamber, rests in the middle of the heart, and is protected by the five senses, just as by some handmaidens. By what kind of senses? By sight, taste, smell, hearing and touch. If, therefore, not one sense has been corrupted and strayed, the soul is kept pure and unharmed. But if it should happen, that sight is left to wander without direction towards the view of youthful beauty, and the violent wave of lust is granted admittance through the eyes into the depth of the heart, immediately, having been struck by a tempest of pleasure, it is carried towards the sin below the surface, suffering shipwreck in regard to chastity. And so, he suffers that very thing which David too, while suffering said: I came into the depths of the sea, and a tempest overwhelmed me (Ps 88.3 LXX). And similarly, hearing too, if opened wide it welcomes the charms of euphony, directing the mind towards those things, and being drawn together with lewd songs, wrecks its entire self. And taste, when carried off by gluttony and much wine towards drunkenness and lasciviousness, corrupts the soul. And smell, when bound by the elaborate perfumes of the young, binds the soul along with itself. In this way, therefore, the soul is betrayed by the senses, like some virgin by foolish handmaidens, and succumbs to the sin of licentiousness. For sin, stupefying all the senses, in the manner of a thief covertly comes into the inner room of the heart, then, upon entering, strips her naked, robbing the whole store of chastity. (On Susanna 23-36)

We now see that the Cappadocian engages in the strategic construction of the ideal, virtuous (and masculine) Christian soul ( $\psi v \chi \eta$ $)$ via the intermediary construction and masculinisation of Susanna. As Susanna was kept safe and chaste like a virgin, who also defended her chastity, so too must each Christian guard their soul and keep it safe and chaste. Susanna's battle now becomes the battle of each person's soul, and each person has the ability to become like Susanna in their daily life. And for this author, and many others, including John Chrysostom, 'true' asceticism was not reserved for the monks in the desert - it was to be practised and embodied in daily life in the city and household (Brown 1988:305-322). Avoiding some of the complicated technicalities of Platonic and/or Stoic psychology (and the precise distribution of the soul in the human body), the author simplifies his discourse and teaching about the soul by locating it in the heart. Some Greek medical authors, like Praxagoras (ca. 340 BCE), did indeed primarily locate the soul in the heart (eds. Irby \& Keyser 2002:14), although here the Cappadocian might possibly be locating the soul in the heart because of the close conceptual proximity of these concepts in biblical literature more generally.
The challenge that each soul faces is to control the senses ( $\alpha i \sigma \theta \eta \dot{\sigma} \sigma 1 \varsigma$ ), which are here likened to the female slaves in the Susanna narrative. And like slaves in the household, the senses need to be controlled, disciplined and subjugated. Using the discourse of slavery, or duology (on which see De Wet 2015:1-39), the author now furthers his agenda of masculinisation in the homily. The focus on chastity as a struggle and exhibition of steadfastness is now supplemented with a call to self-control and the domination of the senses and emotions, another central tenet of ancient Christian masculinity. The author typically understands slaves as surrogate bodies of the master, as has been affirmed by Glancy (2006:11-16). Just as the violation of a slave by a foreign force implies a violation and insult against the master, so too does the violation of the senses threaten the master of the senses, the heart/soul. The author thus uses some of the basics of ancient Roman domestic pedagogy to explain psychological dynamics. This was rather common in ancient thought. Again, in an authentic treatise of John Chrysostom, On Vainglory and the Education of Children 23, we see a similar move (possibly influenced by Plutarch's thought) in which children are taught that the soul of a person, especially a child, is a city: 'Regard yourself as a king ruling over a city which is the soul of your son; for the soul is in truth a city' (translated by Laistner 1951:96 [slightly adapted]). Chrysostom continues to list the senses of the soul as the gates of the city that need to be closely guarded. Both the Cappadocian and Chrysostom use fundamental concepts related to masculinity - the former using slaves in the domestic sphere and the latter civic duty and civil military defence - to explain the notion of guarding the soul and cultivating virtue.

The use of the senses in relation to the soul elevates the discourse further to the realm of daily life. He focusses less on some of the conventional emotions we often see being treated in Chrysostom, such as anger, $\dot{\rho} \alpha \theta u \mu i ́ \alpha$ (usually rendered as 'sloth' or 'indifference'), grief and so on (see especially, Leyerle 2020). Control of the self is lost when the senses are not disciplined, just as a house with insolent slaves cannot function properly. Susanna's steadfastness then functions as a correlate for the steadfastness required from every soul to keep the senses under control and not to allow sin to enter.

And while his psychological discourse remains simple for his audience, the Cappadocian does not hesitate to use the common Platonic notion of the soul needing to wrestle with and withstand animalistic passions. The sinful elders are described in highly visceral and animalistic terms:

Two elders of the people lusted after her, the acknowledged governors of the flock, and each of them burning with the flame of lust, were ashamed to reveal the hidden fire of their heart to one another.... And when she [Susanna] sent her handmaidens away to fetch ointment, both elders ran at her like wolves at a lamb, <and $>$ held $<$ her $>$ down, wanting to tear $<$ her $>$ apart by the insane passion of their licentiousness. And Susannah was alone between the two lions, and no one was her helper, neither servant-girl, nor slave, nor relative, nor friend, nor neighbour, God alone excepted took notice from heaven, he who is able to prevent but who allowed the fight to happen so that he might 
test hidden intentions, and make Susannah's chastity, and the elders' licentiousness public, and at the same time exhibit the virtuous struggle of Susannah <as> the greatest school for women. (On Susanna 40, 45-46)

In contrast to Susanna, the elders, who are supposed to be the torch-bearers of masculinity and self-control, are described in effeminate language. They are not controlled, and burn with fire in their hearts. They are unable to sustain chastity. The Cappadocian then describes them as ravenous wolves and lions, predatory animals that, in this case, represent the appetitive threats to the soul, which are often described in animal imagery. This animal imagery is convenient because it was these types of animals, lions in particular that faced the Christian martyrs in the arena. The lions, now, are the appetites of the soul that need to be conquered. In ascetic literature, such as the Life of Antony, we also see the monks wrestling against demons that often resemble animals. In On Susanna 57, the elders are indeed associated with demons. With reference to Chrysostom's corpus, Leyerle (2019:276-299) also notes that animal imagery signifies and reinforces spatial distinctions. In this case, the elders/wolves/lions represent the untamed wilderness, and Susanna and her maidens the household (or city) that must be guarded from external threats. Unlike the famous martyr Perpetua, from the Passion of Perpetua and Felicitas, who had her slave Felcitas in the arena with her, the Cappadocian points out that Susanna did not have any slave companions in her arena. She fought alone. In this way, he emphasises the agency and independence of Susanna possibly in veiled reference to other female martyrs of early Christian tradition.

\section{Conclusion: Susanna and the construction of salvation history in On Susanna}

In her riveting book on John Chrysostom's use of the emotions in his preaching, Leyerle (2020) rightly notes the centrality of narratives in this process. Leyerle (2020) explains thus:

Through stories, Chrysostom explores the sensations associated with the various emotions, discloses their underlying thought patterns, and traces their impact. But the end he seeks is not purely cognitive. He consistently urges his congregation to enter these narrative worlds, and promises that doing so will transform them. By exposing them to new patterns of feeling and reaction, these narratives enlarge his listeners' understanding of others and of themselves. They teach them that no matter how instinctive or imperative feelings may appear, emotions are neither inevitable nor immutable: they can be altered, and people can react differently. By encouraging identification with the feelings and decisions of the protagonists, as well as execration of the reactions of the antagonists, stories arouse both aversion and longing. Both, if sustained, will effect change. To have this transformative effect, however, stories must become deeply internalized or, in Chrysostom's words, 'inscribed' on the mindset. (p. 186)

Leyerle's above assertion is also true in the case of the Cappadocian's sermon On Susanna. He uses the narrative of Susanna, as we have seen, to teach his audience behavioural principles about the soul and its senses. For the Cappadocian, the spectacular nature of the narrative - its similarity to the martyr narratives of old - exactly invites the audience to become prurient spectators, and to learn from the example of Susanna. Not only are they spectators of Susanna's contest, however, but through the psychic typology deduced from the narrative, the audience is also made aware of their own internal contest between the soul and the passions. The readers are invited not only to consider Susanna's virtue, that is, her masculine disposition, but they are also challenged to fashion their own masculinity while they engage with the narrative. The fashioning of masculinity is performed through creative, psychological narrative engagement. By internalising Susanna, by making her a type for the soul of each listener, each listener is invited to internalise the heroine and to become a Susanna in their souls.

For instance, towards the end of the homily, the author writes:

And the wondrous thing, if you would hear where the skamma [i.e. the athletic jumping pit] had been opened - in a garden, where the serpent deceived Eve. Therefore, as the fight was at hand, the heavens were opened, the trumpet sounded, the contest was ready, the agonothetes [i.e. the contest judge] from heaven turned his attention to the fight, and the company of angels stooping down, observed. The serpent in the lawbreakers, faith in the chaste woman. (On Susanna 51-54)

Having animalised the elders and masculinised Susanna, the Cappadocian transposes the story back into the context of Genesis 1-3 and the temptation of Adam and Eve in the garden. The serpent is now represented by the elders, the final and most extreme instance of their animalisation. But this story does not end in tragedy and failure, as in the original story. By maintaining a masculine stance, Susanna gains the victory that eluded Adam and Eve. In this regard, we see how the masculine failures of some characters, like Adam and Eve, are remedied by masculine victories of others, like Susanna. One narrative serves to correct another. As Susanna is also the internalised soul, so too can the soul of each believer share in the victory of Susanna and overcome the curse of Genesis 1-3.

This is a masterful and effective move by the Cappadocian, as he internalises biblical salvation history, and makes this salvation history eclipse with the very (gendered) subjectivity of the listeners. In On Susanna, the Cappadocian does not merely construct a linear line of biblical salvation history. Rather, he constructs a conceptually layered and highly gendered version of salvation history that draws together various narratives of the Bible, but also brings in the daily struggles of the listeners in their resistance of passion, temptation and sin. The implication is that biblical salvation history is not so much linear as it is a spiral; it repeats itself in various biblical narratives, and the listener is an integral part of that history. When an ordinary Christian adopts a masculine steadfastness against the threats of licentiousness, for instance, he or she engages in the same narrative contest of which Susanna, and many others, like Adam and Eve or Joseph in Egypt, are a part. This study therefore challenges us to reassess how we understand early Christian 
reconstructions of biblical salvation history in relation to one's gendered religious and social identity.

In conclusion, what we witness in this short gem of a homily is the early Christian imperative to reclaim biblical heroes of the past, and to reconstruct them strategically for moral and pedagogical reasons, for a late antique audience. The main thrust of the narrative reconstruction is to present a protagonist, like Susanna, as an exemplum of masculinity, and the antagonists, like the elders, as uncontrolled, effeminate and animalistic dangers to the community. The author does not mind blurring some boundaries between the virgo and the married noble woman - Susanna's lessons are applicable to both, as well as to men. He also recasts Susanna's struggle as a type of Christian martyr narrative in which victory is seen in the steadfastness of chastity. But by shifting the discourse to the realm of the soul, the martyr narrative also becomes a narrative about ó $\sigma \kappa \eta \sigma 1 s$, a concept that also bears athletic overtones (in the sense of 'discipline' and 'training'). Susanna is therefore presented to the audience as a masculine martyr and a monk-like ascetic. But in order to engage his audience in their very subjectivity and identity, he transposes this construction of the masculine martyr-monk Susanna onto the arena of the soul, and allows the audience to imitate Susanna in their own struggles against the passions that threaten the senses of the soul. In so doing, each listener's narrative becomes part of the greater narrative of salvation history, and each ephemeral behavioural victory is seen as on par with the great victory of Susanna (and, essentially, Christ). It was most likely the deployment of intensive subjectivising strategies like these - where the identity of the listener and that of Susanna, in this case, eclipse in the psychic realm - that inspired other early Christian authors to label texts like the narrative of Susanna in LXX Dan 13 useful for 'ecclesiastical' purposes.

\section{Acknowledgements Competing interests}

The author declares that he has no financial or personal relationships that may have inappropriately influenced him in writing this article.

\section{Author's contributions}

C.L.d.W. is the sole author of this article.

\section{Ethical considerations}

This article followed all ethical standards for research without direct contact with human or animal subjects.

\section{Funding information}

This research received no specific grant from any funding agency in the public, commercial or not-for-profit sectors.

\section{Data availability}

Data sharing is not applicable to this article as no new data were created or analysed in this study.

\section{Disclaimer}

The views and opinions expressed in this article are those of the author and do not necessarily reflect the official policy or position of any affiliated agency of the author.

\section{References}

Brown, P.R.L., 1988, The body and society: Men, women, and sexual renunciation in early Christianity, Columbia University Press, New York, NY.

Brown, P.R.L., 2002, Poverty and leadership in the later Roman Empire, University Press of New England, Hanover.

Clark, E.A., 1999, Reading renunciation: Asceticism and scripture in early Christianity, Princeton University Press, Princeton, NJ.

Cloke, G., 1995, This female man of God: Women and spiritual power in the Patristic age, AD 350-450, Routledge, London.

Cobb, L.S., 2008, Dying to be men: Gender and language in early Christian martyr texts, Gender, Theory, and Religion, Columbia University Press, New York, NY

De Wet, C.L., 2009, 'The reception of the Susanna narrative (Dan. XIII) in early Christianity', in J. Cook (ed.), Septuagint and reception: Essays prepared for the association for the study of the Septuagint in South Africa, Supplements to Vetus Testamentum 127, pp. 229-244, Leiden, Brill.

De Wet, C.L., 2012, 'Claiming corporeal capital: John Chrysostom's homilies on the Maccabean martyrs', Journal of Early Christian History 2(1), 3-21. https://doi.org/ 10.1080/2222582X.2012.11877255

De Wet, C.L., 2015, Preaching bondage: John Chrysostom and the discourse of slavery in early Christianity, University of California Press, Oakland, CA.

De Wet, C.L., 2018, 'Old Age, masculinity, and martyrdom in late antiquity: John Chrysostom and the Maccabean martyrs', Journal of Early Christian History 8(1), 43-67. https://doi.org/10.1080/2222582X.2018.1517270

Elm, S., 1996, Virgins of God: The making of asceticism in late antiquity, Clarendon, Oxford.

Gallagher, E.L. \& Meade, J.D., 2017, The biblical canon lists from early Christianity: Texts and analysis, Oxford University Press, Oxford.

Glancy, J.A., 2006, Slavery in early Christianity, Fortress, Minneapolis, MN.

Hunter, D.G., 2007, Marriage, celibacy, and heresy in ancient Christianity: The Jovinianist controversy, Oxford Early Christian Studies, Oxford University Press, Oxford

Irby, G.L. \& Keyser, P.T. (eds), 2002, Greek science of the Hellenistic era: A sourcebook, Routledge, London.

Kuefler, M., 2001, The manly eunuch: Masculinity, gender ambiguity, and Christian ideology in late antiquity, The Chicago Series on Sexuality, History, and Society, University of Chicago Press, Chicago, IL.

Laistner, M.L.W. (transl.), 1951, 'An address on vainglory and the right way for parents to bring up their children by Saint John Chrysostom, Bishop of Constantinople', in M.L.W. Laistner (ed.), Christianity and pagan culture in the later Roman Empire, pp. 85-122, Cornell University Press, Ithaca, NY.

Leyerle, B., 2019, 'Locating animals in John Chrysostom's thought', in C.L. De Wet \& W. Mayer (eds.), Revisioning John Chrysostom: New approaches, new perspectives, Critical Approaches to Early Christianity 1, pp. 276-99, Brill, Leiden.

Leyerle, B., 2020, The narrative shape of emotion in the preaching of John Chrysostom, University of California Press, Oakland, CA.

Maxwell, J.L., 2009, Christianization and communication in late antiquity: John Chrysostom and his congregation in Antioch, Cambridge University Press, Cambridge.

Mayer, W. (transl.), 2006, The cult of the saints, Popular Patristics Series, St. Vladimir's Seminary Press, Crestwood, NY.

Migne, J.-P. (ed.), 1862, Patrologiae cursus completus: Series graeca, vol. 56, Migne, Paris.

Papadopoulos, K., 2017, 'Ps.-Chrysostom De Susanna sermo (PG 56: 589-594 = CPG 4567): Draft translation', Academia.edu., viewed 25 July 2021, from https://www. academia.edu/33427701/Ps_Chrysostom_De_Susanna_Sermo PG_56_589_594_CPG_4567_Draft_Translation.

Praet, D., 2011, 'Susanna, the fathers and the Passio Sereni (BHL 7595-6): Sexual morals, intertextuality and early Christian Self-Definition', Zeitschrift für Antikes Christentum 14(3), 556-580. https://doi.org/10.1515/zac.2010.30

Shaw, B.D., 1996, 'Body/power/identity: Passions of the martyrs', Journal of Early Christian Studies 4(3), 269-312. https://doi.org/10.1353/earl.1996.0037

Voicu, S.J., 2013, 'L'omelia Quod filii debeant honorare parenetes (CPG 5092) di uno Pseudocrisostomo Cappadoce', in A.M. Piazzoni (ed.), Studi in onore del Cardinale Raffaele Farina II, Studi e testi 478, pp. 1197-1221, Biblioteca Apostolica Vaticana, Vatican City.

Walsh, E.M., 2008, 'Wealthy and impoverished widows in the writings of St. John Chrysostom', in S.R. Holman (ed.), Wealth and poverty in early church and society, Holy Cross Studies in Patristic Theology and History, pp. 176-186, Baker Academic, Grand Rapids, MI.

Wilkinson, K., 2015, Women and modesty in late antiquity, Cambridge University Press, Cambridge. 